\title{
ИЗМЕНЕНИЕ ГИДРОГЕОЛОГИЧЕСКИХ УСЛОВИЙ ШИРВАНСКОЙ СТЕПИ АЗЕРБАЙДЖАНА ПОД ВЛИЯНИЕМ АНТРОПОГЕННЫХ ФАКТОРОВ
}

\author{
Ч. Д. Гюльмамедов \\ Азербайджанское научно-производственное объединение \\ «Гидротехника и Мелиорация", Азербайджан
}

Поступила в редакцию 18 января 2019 г.

\begin{abstract}
Аннотация: целью исследования являлось изучение гидрогеологических условий Ширванской степи Азербайджана и изменения её под влиянием антропогенных факторов. Выявлено, что в связи с проведением различных гидрогеолого-мелиоративных мероприятий, наиболее значительные изменения гидрогеологических условий равнины наблюдались после 1958 г., когда были введены в эксплуатацию Верхне-Ширванский канал и в 1964 г. - Главный Ширванский коллектор. С этого времени отмечался постоянный подъём уровня грунтовых, а в некоторых случаях и напорных вод. Под влиянием оросительной мелиораиии уровень грунтовых вод (УГВ) в течение 80 лет (1930-2010 гг.) поднялся более чем на 4,2 м, т.е. от 6,04 до 1,79 м. В 1930 г. УГВ Ширванской степи залегал на глубине 5-10 м, а начиная с 1951 г. он начал подниматься в связи со строительством водохранилищ, ирригаџионно-оросительных систем, увеличением оромаемых площадей. $B 19802$. УГВ поднялся более чем 3 раза. В 1995 г. УГВ до 3 м охватывал 90-95\% всей площади степи. В последующие годы поднятие УГВ начало ослабевать и происходила стабилизаџия. Поднятие УГВ связано, в основном, $c$ отсутствием или плохой работой коллекторно-дренажной системы. Соответственно режиму УГВ формируется их минерализащия. Минерализация ГВ в течение 80 лет, за счёт разбавления поверхностных вод и отвода высокоминерализованных вод посредством дренажа, уменьшилась примерно на 13,8 г/л или от 28,6 до 14,8 г/л. Почти на всей площади равнины режим формируется под воздействием искусственных факторов, основными из которых являются орошение земель и дренаж. По этой причине климатический тип режима трансформировался в ирригационно-климатический.

Ключевые слова: грунтовые воды, напорные воды, минерализация, химический состав, режим, антропогенные факторы.
\end{abstract}

\section{CHANGE OF HYDROGEOLOGICAL CONDITIONS OF SHIRVAN STEPPE OF AZERBAIJAN UNDER THE INFLUENCE OF ANTHROPOGENOUS FACTORS}

\begin{abstract}
Shirvan steppe of Azerbaijan under the influence of anthropogenous factors. It was revealed that in connection with the implementation of various hydrogeological meliorative actions measures, the most considerable changes in the hydrogeological conditions of the plain were observed after 1958 when have been put into operation the Upper-Shirvan channel in 1964. Main Shirvan collector. Since that time, there has been a steady rise in the level of groundwater, and in some cases, pressurized water. Under the influence of irrigation melioration, the level of groundwater in the course of 80 years (1930-2010) rose more than $4.2 \mathrm{~m}$, from 6,04 to $179 \mathrm{~m}$. In 1930, the level oground waters (LGW) of the Shirvan steppe fell to a depth of 5-10 m, and since 1951 it has risen. In connection with the construction of reservoirs, irrigational and irrigation areas in 1980, the LGW rose 3-fold. In 1995, the LGW covered up to $3 \mathrm{~m} 90-95 \%$ of the entire steppe area. In the next years the raising of $L G W$ has begun to weaken and stabilization occurs. The raising $(L G W)$ is generally connected with absence or bad work of collector-drainage system. In accordance with the GW regime, their mineralization is formed. The mineralization of GWA for 80 years due to dilution of surface water and drainage of highly mineralized water by drainage has decreased by about 13,8 g/l or from 28,6 to $14,8 \mathrm{~g} / \mathrm{l}$. Almost on the entire area of the plains, the regime is formed under the influence of artificial factors, the main of which are irrigation and drainage. For this reason, the climatic type of regime was transformed by irrigation-climatic.
\end{abstract}

Key words: groundwater, pressure water, mineralization, chemical composition, regime, anthropogenic factors. 


\section{Введение}

Социально-экономическое развитие страны определяется количеством и качеством её земельных и водных ресурсов. Эти ресурсы в Азербайджане ограничены и из года в год они интенсивно подвергаются техногенному воздействию.

Ширванская степь является одной из основных сельскохозяйственных территорий республики. В связи с мелиоративными мероприятиями и добычей подземных вод гидрогеологические условия здесь значительно изменились. Для освоения засоленных и улучшения мелиоративного состояния орошаемых земель территории в 1953 г. построено и сдано в эксплуатацию Мингечаурское водохранилище. В результате этого широко развернулась реконструкция существующих ранее построенных оросительных систем и орошение новых земель.

Наиболее значительные изменения гидрогеологических условий равнины наблюдались после 1958 г., когда были введены в эксплуатацию ВерхнеШирванской канал, взявший свое начало с Мингечаурского водохранилища, с расходом 78 м $3 /$ сек., длиной 123 км и в 1964 г. - Главный Ширванский коллектор для отвода лишних подземных вод территории длиной 211 км с расходом $37 \mathrm{~m}^{3} /$ сек. С этого времени отмечается постоянный подъём уровня грунтовых, а, в некоторых случаях, и напорных вод на многих подкомандных каналу участках [1].

В республике, в связи с ограниченным количеством поверхностных вод, широко используются подземные воды. Из-за проведения мелиоративных мероприятий и использования подземных вод, гидрогеологические условия коренным образом изменились от начального, т.е. изменился уровень и минерализация подземных вод, происходило истощение, загрязнение и изменение физического, химического и биологического их состава, происходит активизация экзогенных процессов, вторичное засоление земель и другие процессы. Поэтому изучение антропогенного и природного воздействия на гидрогеологические условия территории являются актуальной задачей современного времени.

Цель статьи - изучение гидрогеологических условий Ширванской степи и их изменения в результате воздействия гидрогеолого-мелиоративных мероприятий.

Объектом исследования является Ширванская степь Кура-Араксинской низменности (КАН) Азербайджана.

\section{Методика исследования и материалы}

Изменение гидрогеологических условий Ширванской степи Азербайджана изучено по режиму уровня, минерализации и химическому составу подземных вод. С этой целью собраны, обработаны, систематизированы и подвержены научному анализу многолетние (с 1930 по 2010 гг.) материалы Управления геологии Азербайджана (ныне Национальные Геолого- разведочные Службы Министерства Экологии и Природных Ресурсов Азербайджанской Республики), Гидрогеолого-мелиоративной экспедиции Азербайджана (ныне Управление Гидрогеолого-Мелиоративной Службы при ОАО «Мелиорации и Водного хозяйства»), АзНИИГиМа (ныне Азербайджанское научно-производственные объединение гидротехники и мелиорации) и литературные, полевые-опытные данные, полученные автором данной работы в период с 1977 по 2010 гг.

КАН расположена в центральной части Азербайджана. В северной и северо-восточной её части расположена Ширванская степь площадью 680 тыс. га или $28,6 \%$ от всей площади низменности. В административном отношении эта территория делится на районы: Агдашский, Геокчайский, Зардобский, Уджарский, Кюрдамирский и Ахсуинский.

Климат степи - континентальный, теплый. Среднегодовая температура составляет 14,0-14,5 . Атмосферные осадки величиной 200-500 мм в год в основном выпадают в осенне-земнее время. Относительная влажность воздуха наиболее высокая зимой - 75-85\%, а наименьшая летом - 50-62\% [2]. Характерной особенностью климата является резкое преобладание испарения над количеством выпадающих осадков. Испарение с водной поверхности достигает 1200$1500 \mathrm{мм} /$ год [2].

Гидрографическая сеть Ширванской степи достаточно своеобразна и является основным источником водно-солевого питания. Она представлена реками, ирригационными каналами, коллекторно-дренажной сетью, водохранилищами и озерами [3]. С южного склона Главного Кавказского хребта через Ширванскую степь протекает ряд речных артерий. Крупнейшими реками степи являются левые притоки р. Куры: Алджиганчай, Турианчай, Геокчай, Гирдыманчай и Ахсучай. По характеру водного режима все реки относятся к группе с весенним или весенне-летним половодьем и осенними паводками. Среднемноголетние годовые расходы рек колеблются от 1,78 м³/c (p. Ахсу, п. Ахсу) до 17,6 м³/с. (р. Турианчай, гидроузел) [4, 5].

Ширванская степь в тектоническом и геоморфологическом отношении является межгорной впадиной и представляет собой область опускания и накопления осадков. Продолжительность её формирования, начиная с нижнего майкопа, оценивается более 37 млн лет [4]. С тектонической точки зрения здесь выявлены крупные разломы и трещины в параллельном и меридиональном направлении, а также многочисленные (до 19) выступы [4].

Ширванская предгорная равнина на всю разведанную глубину (300-400 м) сложена континентальными образованиями средне- и верхнечетвертичного возраста [6-8]. В отличие от других равнин республики здесь сложены не первичные, а вторичные конусы выноса рек, стекающих с юго-западного склона Кавказа. Реки, создающие мощные конусы выноса в пределах Алазань-Агричайского равнины, прорезают 
возвышенность Аджиноура, сложенную глинистыми породами и доносят до Ширванской равнины в основном только мелкозернистый материал [8].

До глубины 300-400 м в пределах равнины вскрыто и изучено четыре водоносных горизонта - грунтовый и три напорных [7]. Грунтовые воды распространены повсеместно в толще делювиальных, пролювиальных и аллювиальных отложений и залегают на различных глубинах. Наибольшая глубина залегания уровня грунтовых вод наблюдается в предгорьях более 10 м, а наименьшая - в центральной части, вдоль водоемов, водотоков и на орошаемой территории 1-3 м. Абсолютные отметки УГВ изменяются от 200-260 м в районе г. Ахсу и до минус 7,5 м по южной границе равнины [7].

Уклон потока грунтовых вод -0,03-0,0007, уменьшается от предгорий к р. Куры. В этом же направлении уменьшается мощность горизонта от 110-178 м до 5-10 м. Дебиты скважин 0,05-118 л/с при удельных дебитах 0,02-5,4 л/с м. Коэффициент фильтрации водосодержащих пород колеблется от 0,1 до 64,0 м/сут, наибольшие значения (10-20 м/сут) отмечены на участках в приверщинных частях конуса выноса рек Турианчай и Ахсучай [9]. В межконусных понижениях и по периферии конусов распространены тяжелые грунты с коэффициентами фильтрации 0,05-1 м/сут. Коэффициент водопроводимости грунтового водоносного горизонта на большей части площади не превышает $10 \mathrm{~m}^{2} /$ сут, достигая в некоторых случаях значений в 10-25 $\mathrm{M}^{2} /$ сут. Большие значения (до $75 \mathrm{~m}^{2} /$ сут.) отмечаются только в привершинных и центральных частях конусов выноса $[9,10]$.

Режим грунтовых вод преимущественно управляет режимом напорных вод. В связи с водоснабжением населённых пунктов, развитием орошения, уточнением глубоколежащих слоев и характером содержащихся в них вод, различными организациями в разное время было пробурен ряд разведочных скважин глубиной от 30 до 400 м. В толще до 400 м наблюдаются 3 напорных водоносных горизонта, расположенных поэтажно, ниже грунтовых вод [9]. За региональное водоупорное ложе грунтовых вод принимают резкую смену пород песчано-глинистого состава на глинистые породы, имеющие мощность от 10 до 50 м и изолирующие нижележащие водоносные горизонты от грунтовых вод [6].

Первый напорный водоносный горизонт вскрывается скважинами по всей территории степи на глубинах 13-128 м. От грунтового горизонта он отделен глинами мощностью 5-85 м. Водосодержащие породы представлены гравийно-галечниками, песками и супесями мощностью от 3 до 170,7 м, уменьшаясь с северо-запада на юго-восток по конусам выноса, коэффициенты фильтрации коллекторов 0,2-27,9 м/сут. $[6,8]$.

На большей части Алджиганчай-Турианчайского участка пъёзометрические уровни лежат ниже поверхности земли на - 0,9-16,5 м, на Геокчайском участке - как ниже, так и выше поверхности земли: $+7,2-20,8$ м, на Гирдыманчай-Ахсуинском участке выше поверхности земли: $+8,2-+0,4$ м. Абсолютные отметки уровней уменьшаются вниз по рельефу от 76,3 до 0 м. Уклоны потока 0,02-0,0007. Дебиты скважин Алджиганчай-Турианчайского участка до 13,3 л/с, Геокчайский до 9,2г/л, Гирдиманчай-Ахсуинский $1,4 г / л[6,8]$.

Второй напорной водоносной горизонт развит в целом примерно так же на площадях, что и первый за исключением конуса выноса р. Алджиганчай, где территория его развития значительно меньше. Вскрывается на глубинах 75-274 м, от вышележащего горизонта отделен толщей глин мощностью 6-160 м, чаще 30-90 м. Коллектора горизонта - гравийно-галечники, пески и супеси имеют мощности 3,6-73,8, чаще 10-40 м. Коэффициенты фильтрации водосодержащих пород 0,1-35,3 м/сут, коэффициенты водопроводимости - 10-30 м²/сут [4, 6].

На Гирдыманчай-Ахсуинском участке пьезометрические уровни лежат выше поверхности земли $(+19,1-+2,9$ м), на Геокчайском участке как выше, так и ниже поверхности земли (+16,4-3,7 м), на Алджиганчай - Турианчайском участке в подавляющем большинстве случаев ниже поверхности земли $(6,0-$ 14,5 м). Уклоны потока изменяются от 0,02 до 0,0004 . Дебиты скважин при откачках доходят до 6,7 л/с, при самоизливе - до 8,3 л/с, при удельных дебитах 0,011,0 реже до 2,7 л/с м [8].

Третий напорный водоносный горизонт в пределах изученных глубин вскрыт на значительно меньшей территории, чем вышележащие - на АлджиганчайТурианчайском участке и на конусе выноса р. Гирдыманчай. На Геокчайском участке он вообще не вскрыт. Глубина залегания кровли горизонта 62-316 м. От второго напорного горизонта он отделен толщей глин мощностью 7-165 м, чаще 10-80 м. Водосодержащие породы представлены, в основном, мелко и тонкозернистыми песками, супесями с прослойками глин. Мощность горизонта - 4,5-86,4 м, чаще не выходит за пределы 20-70 м [4, 8].

Коэффициент фильтрации коллекторов 0,1-17,9 м/сут, обычно не превышает 9 м/сут. Пьезометрические уровни почти на всей территории лежат выше поверхности земли (от+9 до 43,2 м). Уклоны потока 0,05-0,004. Дебиты скважин при самоизливе до 7,1 л/с, при откачках - до 4,1 л/с, при удельных дебитах до 0,8 л/с, реже - до 3,8 л/с $[4,7]$.

Все водоносные горизонты четвертичных континентальных отложений имеют общие источники питания [3]. В центральных частях конусов выноса происходит перераспределение стока между отдельными горизонтами, а по периферии и на низменности - разгрузка нижележащих горизонтов в вышележащие путём перетекания. Коллектора отдельных горизонтов не выдержаны в плане и разрезе, что способствует связи между их водами. Поэтому вся водоносная толща может рассматриваться как единый комплекс подземных вод. Эффективная мощность этого ком- 
плекса колеблется от единицы до 196 м, коэффициенты водопроводимости до 1,1 тыс. $\mathrm{m}^{2} /$ сут.

\section{Результаты исследований}

На основании результатов научных исследований, проведенных автором, а так же по анализам материалов бывшего Азгеологоуправления (ныне Национальные Геолого-разведочные Службы Министерства Экологии и Природных Ресурсов Азербайджанской Республики) и Гидрогеолого-мелиоративной экспедиции (ныне Управление Гидрогеолого-Мелиоративной Службы при ОАО «Мелиорации и Водного хозяй- ства») [4] Республики составлены карты (рис. 1, 2, 3, 4) на май месяц (с 1930 по 2010 гг. через каждые 10 лет) и рассчитаны площади распространения ГВ по различным глубинам залегания (табл. 1) и минерализации (табл. 2). Как видно из табл. 1, под влиянием оросительной мелиорации УГВ в течение 80 лет поднялся более чем на 4,2 м, т.е. от 6,04 до 1,79 м (табл. 1). В 1930 г. УГВ Ширванской степи залегал на глубине 5-10 м. Начиная с 1951 года, УГВ поднялся по всей КАН, а также и в Ширванской степи. Глубина залегания грунтовых вод до 3 м охватывала 40-50\%, а глубже 5-ти м около $20 \%$ от общей площади степи.

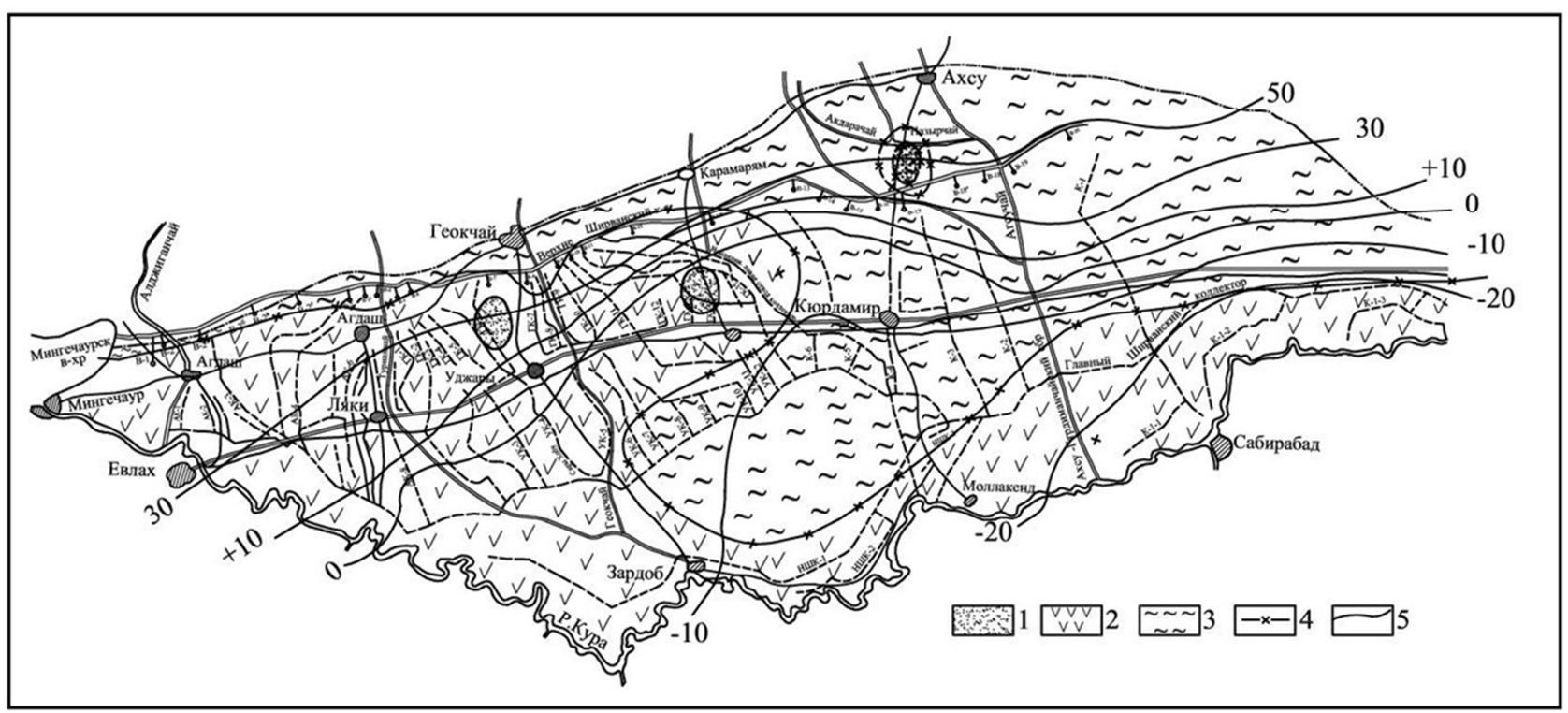

Puc. 1. Схематическая карта гидроизогипс и глубин залегания УГВ Ширванской степи (по состоянию на 20.05.1950 г., составлена Ч. Д. Гюльмамедовым). Условные обозначения: уровень грунтовых вод: 1) 2,5 - 3,0 м.; 2) 3,0 - 5,0; 3) более 5,0 м.; 4) границы участков с различными глубинами залегания грунтовых вод; 5) линии гидроизогипс.

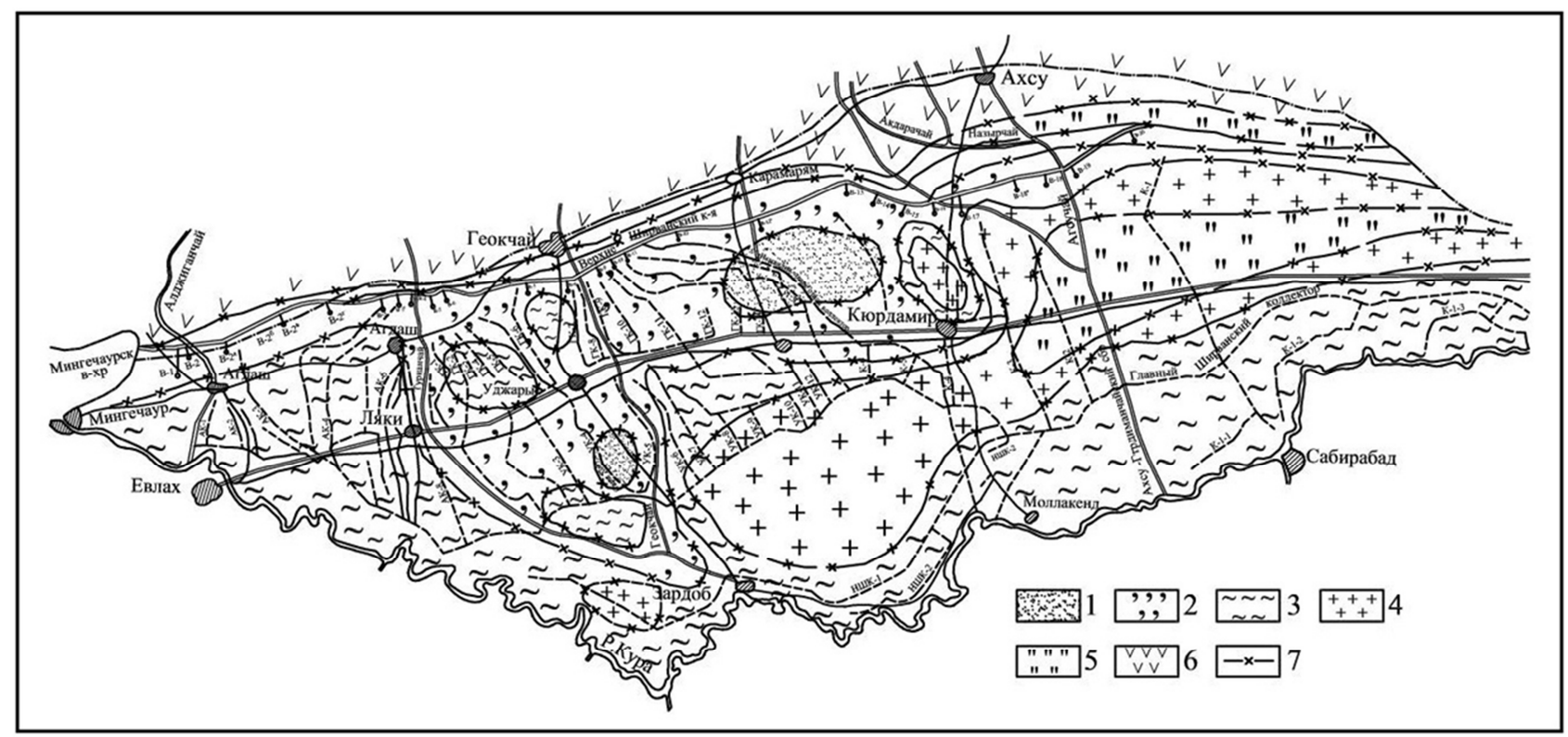

Puc. 2. Схематическая карта глубин залегания УГВ Ширванской степи (по состоянию на 20.05.2010 г., составлена Ч. Д. Гюльмамедовым). Условные обозначения: уровень грунтовых вод: 1) до 1,0 м.; 2) 1,0 - 1,5; 3) 1,5 - 2,0; 4) 2,0 - 2,5; 5) 2,5 - 3,0; 6 ) $3,0-5,0 ; 7)$ границы участков с различными глубинами залегания грунтовых вод. 


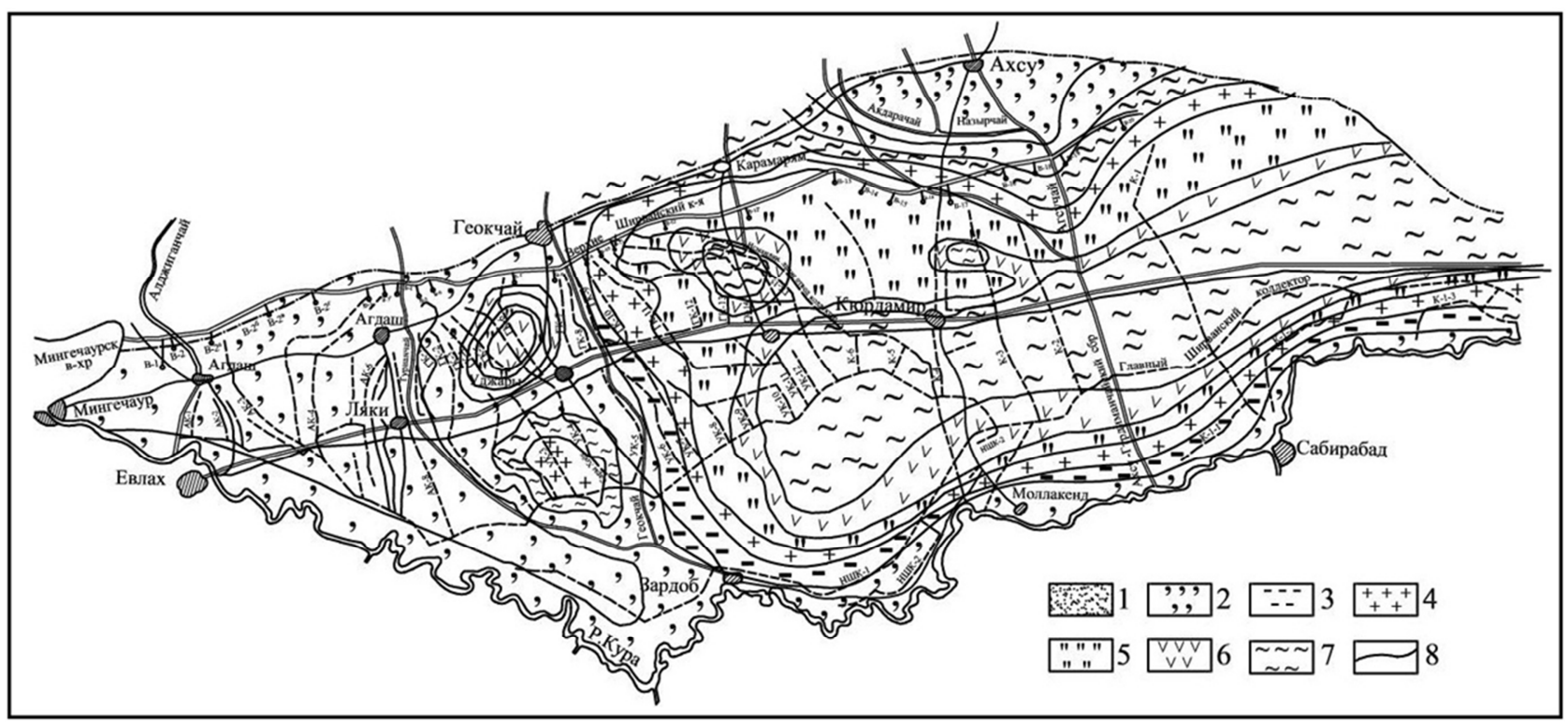

Puc. 3. Схематическая карта общей мелиаризации грунтовых вод Ширванской степи (по состоянию на 20.05.1950 г, составлена Ч. Д. Гюльмамедовым). Условные обозначения: минерализация ГВ: 1) до 1 г/л; 2) 1 - 3; 3) 3 - 5; 4) 5- 10; 5) 10 - 25; 6) 25 - 50; 7) более 5 г/л; 8) границы между различными минерализациями грунтовых вод.

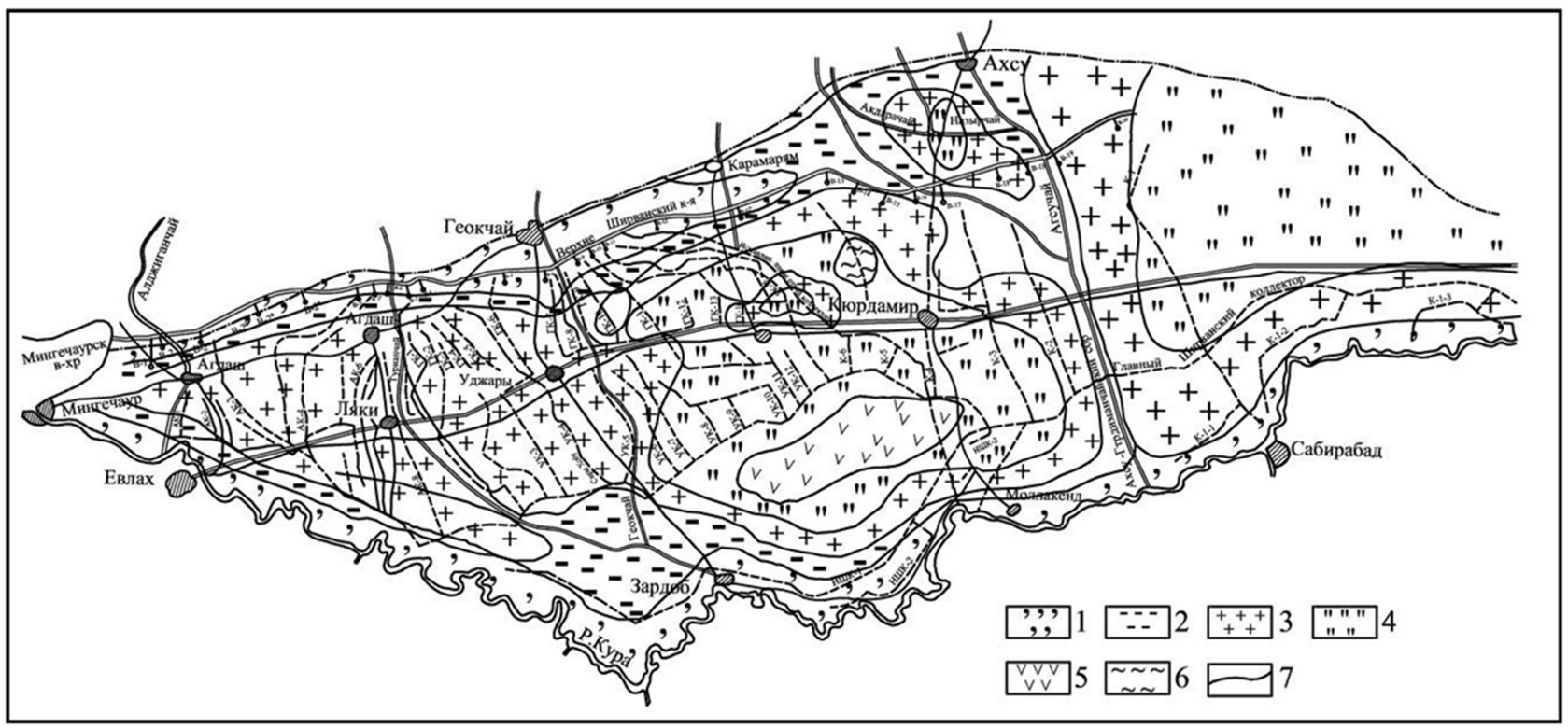

Puc. 4. Схематическая карта общей минерализации грунтовых вод Ширванской степи (по состоянию на 20.05 .2010 г., составлена Ч. Д. Гюльмамедовым). Условные обозначения: минерализация ГВ (г/л): 1) 1-3; 2) 3-5; 3) 5-10; 4) 10-25; 5) 25-50; 6) более $50 ; 7)$ границы между участками с разной минерализацией грунтовых вод.

Таблица 1

Глубина залегания уровня грунтовых вод Ширванской степи на середину мая. Общая площадь 680 тыс. га [1, 5].

\begin{tabular}{|c|c|c|c|c|c|c|c|c|}
\hline \multirow{2}{*}{ Годы } & \multicolumn{6}{|c|}{ Распределение площадей (в \%) от расчетной площади глубины залегания УГВ, $M$} & $\begin{array}{c}\text { Средневзвешен- } \\
\text { носе значение } \\
\text { УГВ, } \boldsymbol{c}\end{array}$ \\
\hline 1930 & $<1$ & $1-2$ & $2-3$ & $3-4$ & $4-5$ & $5-10$ & 10 & 6,04 \\
\hline 1950 & 4,4 & 5,8 & 10,2 & 12,5 & 13,4 & 30,1 & 23,6 & 5,80 \\
\hline 1960 & 11,3 & 12,2 & 20,2 & 14,2 & 10,0 & 19,2 & 12,9 & 3,99 \\
\hline 1970 & 21,2 & 26,2 & 24,1 & 10,4 & 5,8 & 7,2 & 5,1 & 2,38 \\
\hline 1980 & 31,3 & 34,1 & 29.0 & 5,3 & 3,6 & 4,4 & 2,2 & 2,35 \\
\hline 1990 & 23,6 & 38,8 & 28,5 & 4,3 & 2,3 & 2,5 & 0,6 & 2,02 \\
\hline 2000 & 26,2 & 40,2 & 29,9 & 1,8 & 1,2 & 1,1 & 0,3 & 1,98 \\
\hline 2010 & 22,9 & 39,0 & 28,1 & 4,3 & 2,8 & 1,8 & 1,1 & 1,79 \\
\hline
\end{tabular}


Таблица 2

Минерализаџия грунтовых вод Ширванской степи на середину мая. Общзая площзадь 680 тыс. га [1,5].

\begin{tabular}{|c|c|c|c|c|c|c|c|c|c|}
\hline \multirow{2}{*}{ Годы } & \multicolumn{8}{|c|}{ Распределение площадей (в \% от расчетной) по градациям минерализации ГВ, г/л } & \multirow{2}{*}{$\begin{array}{c}\text { Средне-взвешенное } \\
\text { значение минера- } \\
\text { лизации ГВ, } M\end{array}$} \\
\hline & $<1$ & $1-3$ & $3-5$ & $5-10$ & $10-25$ & $25-50$ & $50-75$ & $>75$ & \\
\hline 1930 & 6,3 & 8,6 & 13,1 & 15,0 & 15,3 & 15,9 & 13,9 & 12,9 & 28,6 \\
\hline 1950 & 4,2 & 6,3 & 9,4 & 14,9 & 17,3 & 18,1 & 15,2 & 14,5 & 31,5 \\
\hline 1960 & 2,1 & 4,4 & 6,2 & 15,8 & 18,6 & 20,3 & 16,4 & 16,2 & 34.4 \\
\hline 1970 & 3,6 & 4.9 & 7,8 & 15,4 & 17,9 & 19,2 & 16,8 & 15,4 & 33,6 \\
\hline 1980 & 10,0 & 15,2 & 15,3 & 16,8 & 13,7 & 11,0 & 10,3 & 8,7 & 21,5 \\
\hline 1990 & 13,1 & 16,1 & 17,4 & 18,2 & 13,1 & 7,3 & 7,6 & 6,9 & 17,3 \\
\hline 2000 & 18,2 & 28,9 & 16,8 & 17,5 & 11,9 & 6,9 & 6,2 & 4,3 & 14,8 \\
\hline 2010 & 14,0 & 43,2 & 17,0 & 11,3 & 6,3 & 3,4 & 2,8 & 2,0 & 15,4 \\
\hline
\end{tabular}

В связи со строительством водохранилищ, ирригационно-оросительных систем, увеличением орошаемых площадей, УГВ продолжал подниматься [11]. В 1980 г. УГВ степи по сравнению с 1950 г. поднялся в 3 раза, приближаясь к поверхности земли. В 1995 году УГВ до 3 м охватывал 90-95\% всей площади степи. В последующие годы повышение УГВ начало ослабевать и происходила стабилизация. В степи сформировался гидроморфный режим. Поднятие УГВ в основном связано с отсутствием или плохой работой коллекторно-дренажной системы (КДС) и продолжением процесса засоления почвогрунтов. В связи с региональным подъемом УГВ расход воды на суммарное испарение в 1985 г. был в 2-3 раза больше, чем в 1950 г.

С изменением УГВ изменяется и их минерализация. Минерализация ГВ в течение 80 лет, за счёт разбавления поверхностных вод и отвода высокоминерализованных вод посредством дренажа уменьшилась примерно на 13,8 г/л или от 28,6 до 14,8 г/л (табл. 2).

Как видно из табл. 2 минерализация грунтовых вод в 1950-60-х годах колебалась от 1,0 до 150 г/л, иногда достигая до 200 г/л. Начиная с 1960 г., в связи с вводом новых ирригационных систем, началось постепенное уменьшение минерализации грунтовых вод. Анализы показывают, что снижение минерализации грунтовых вод связано не только с инфильтрацией орошаемых вод и питанием ими грунтовых вод, а также функционированием на территории КДС.

В результате анализа режима уровня и минерализации ГВ выявились следующие закономерности: для орошаемой территории характерно понижение минерализации грунтовых вод при одновременном повышении их уровня, за счёт разбавления оросительной водой и отвода дренажными системами; на перелогах и солончаках, а также на промежуточных площадях между орошаемыми и солончаковыми территориями характерно увеличение минерализации ГВ, при понижении или повышении их уровня вследствие испарения и гидратации. Повышение минерализации на отдельных участках при подъёме УГВ объясняется захватыванием солей из почвенно-грунтовой толщи на пути подъёма [12]. На большей части степи, особенно в восточной и центральной её частях, минерализация ГВ не меняется как при повышении, так и при пони- жении их уровней, что обуславливается равноденствием противоположно направленных факторов.

Изменение гидрогеологических условий под влиянием техногенного воздействия ясно видно из многолетнего анализа (с 1950 по 2010 гг.) режима подземных вод (рис. 1, 2, 3, 4). На основании данных автора и бывшего Азгеологоуправления изучен режим (изменение УГВ, минерализация и температура) подземных вод. Почти на всей площади равнины режим формируется под воздействием искусственных факторов, основными из которых являются орошение земель и дренаж. При сильно разветвленной оросительной сети и увеличении орошаемых площадей водоподача выступает как региональный фактор формирования режима, подчиняющий своему влиянию ход колебания уровня. По этой причине климатический тип режима трансформировался в ирригационноклиматический. С начала года по март месяц уровни подземных вод при ирригационно-климатическом и ирригационно-дренажном типах режима практически стабильны. Затем начинается подъём уровней, связанный с выпадением атмосферных осадков и началом поливов. Высокие уровни поддерживаются до конца вегетации, после чего начинается их медленный спад. На фоне общего высокого стояния уровней отмечаются отдельные пики, соответствующие по времени срокам подачи воды на орошение. На массивах, где развита коллекторно-дренажная сеть, в многолетнем разрезе происходит понижение уровней подземных вод, интенсивность которого зависит от протяженности дренажных систем, давности их сооружений и других причин. В целом годовая амплитуда колебаний уровня грунтовых вод изменяется от 0,05 до 2 м [5].

Для напорных вод (в течение года) годовая амплитуда составляет 0,1-1,5 м, изредка до 2,6 м [8].

Мелиорация земель сыграла значительную роль и в изменении качественного состава грунтовых вод. По данным проводимым Ф. Ш. Алиева, с 1963 г. с территории равнины дренажными водами ежегодно выносится 3,2 млн тонн солей [8]. Это приводит к сокращению площади с высокой минерализацией грунтовых вод. Для напорных вод в течение года часто отмечаются значительные колебания общей минерализации и химического состава воды, которые, однако, 
имеют циклический характер.

Расширение орошаемых площадей и увеличение водоподачи на массивах приводит в некоторых случаях к ухудшению мелиоративного состояния земель. Это заставляет со всей серьезностью заняться вопросом прогнозирования режима грунтовых вод этих земель.

\section{Заключение}

В пределах равнины до глубины 300-400 м вскрыты и изучены четыре водоносных горизонта - грунтовый и три напорных. Под влиянием оросительной мелиорации и добычи подземных вод, в течение 80 лет УГВ поднялся на 4,25 м (с 6,04 до 1,79 м), а минерализация их за счёт разбавления поверхностных и отвода минерализованных вод посредством дренажа, уменьшилась на 13,8 г/л или от 28,6 до 14,8 г/л. Почти на всей площади равнины режим формируется под воздействием искусственных факторов, основными из которых являются орошение земель и дренаж. По этой причине климатический тип режима трансформировался в ирригационно-климатический.

\section{ЛИТЕРАТУРА}

1. Алимов, А. К. Гидрогеологические процессы и количественные оценки источников формирования элементов водно-солевого баланса грунтовых вод для обоснования гидрогеолого - мелиоративных прогнозов. / А. К. Алимов. - Баку: Элм, 2001. - 294 с.

2. Шыхлинский, Э. М. Климат Азербайджана. / Э. М.

Шыхлинский. - Баку: Из-во АН Азерб. ССР, 1968. - 343 с.

3. Алимов, А. К. Ирригационные каналы и их влияние на

Азербайджанское научно-производственное объединение «Гидротехника и Мелиораичия,, Азербайджан, г. Баку,

Гюльмамедов Чингиз Джахангир оглы, кандидат геологоминералогических наук, доиент

E-mail: gcin56@mail.ru

Тел.: +994503793845 экологическую обстановку. / А. К. Алимов. - Баку: Элм, 2009. $-92 \mathrm{c}$.

4. Геология Азербайджана, т.VIII, «Гидрогеология и инженерная геология». / А. А. Ali-zade. - Баку: Из-во «NaftaPress», 2008. $-368 \mathrm{c}$.

5. Гюльмамедов, Ч. Д. Закономерности формирования солевых запасов подземных вод континентальной толщи четвертичных отложений Турианчай - Ахсучайского междуречья Ширванской степи. / Ч. Д. Гюльмамедов // Автореферат диссертации на соискание уч. степени кандидата геологоминералогических наук. Баку: 1987. -25 с.

6. Листенгартен, В. А. Закономерности формирования, особенности методики оценки ресурсов и перспективы использования маломинерализованных подземных вод равнин Азербайджанской ССР / В. А. Листенгартен. - Из-во. Элм, Баку, 1983. -272 c.

7. Листенгартен, В. А. Формирование ресурсов подземных вод аллювиально - пролювиальных равнин / В. А. Листенгартен. - Баку: Из-во. Элм, 1987. - 164 с.

8. Алиев, Ф. Ш. Подземные воды Азербайджанской республики, использование запасов и геологические проблемы. / Ф. Ш. Алиев. - Баку: Чашыоглы, 2000. - 325 с.

9. Исрафилов, Г. Ю. Грунтовые воды Кура-Араксинской низменности. / Г. Ю. Исрафилов. - Баку: «Маариф», 1972. $-206 \mathrm{c}$.

10. Исрафилов, Ю. Г. Формирование, прогноз и рациональное использование ресурсов пресных подземных вод предгорных равнин Азербайджанской Республики. / Ю. Г. Исрафилов // Автореф. на соиск. уч. степ. д.г.-м.н., Баку: 2005. - 48.c.

11. Каџ, Д. М. Влияние орошения на грунтовые воды. / Д. М. Кац. - М.: Колос, 1976. - 271 с.

12. Геология и гидрогеология предгорных равнин. / С. А. Али-заде [и др.]. - М.: Недра, 1990. - 247c.

Azerbaijan Scientific and Production Association of «Hydraulic engineering and melioration», Azerbaijan, Baku

Gyulmamadov Ch. J., Doctor of Geological and Mineralogical Sciences, associate professor

E-mail:gcin56@mail.ru

Tel.: +994503793845 